\title{
Sustainability, certification, and regulation of biochar
}

\author{
Frank G. A. Verheijen ${ }^{(1)}$, Luca Montanarella(2) and Ana Catarina Bastos ${ }^{(3)}$ \\ (1)University of Aveiro, Centre for Environmental and Marine Studies (CESAM), Department of Environment and Planning, \\ 3810-193 Aveiro, Portugal. E-mail: frankverheijen@gmail.com ${ }^{(2)}$ European Commission Joint Research Centre, Via E. Fermi 2749, Ispra, Italy. \\ E-mail: luca.montanarella@jrc.ec.europa.eu ${ }^{(3)}$ University of Aveiro, CESAM, Department of Biology. E-mail: a.c.bastos@ua.pt
}

\begin{abstract}
Biochar has a relatively long half-life in soil and can fundamentally alter soil properties, processes, and ecosystem services. The prospect of global-scale biochar application to soils highlights the importance of a sophisticated and rigorous certification procedure. The objective of this work was to discuss the concept of integrating biochar properties with environmental and socioeconomic factors, in a sustainable biochar certification procedure that optimizes complementarity and compatibility between these factors over relevant time periods. Biochar effects and behavior should also be modelled at temporal scales similar to its expected functional lifetime in soils. Finally, when existing soil data are insufficient, soil sampling and analysis procedures need to be described as part of a biochar certification procedure.
\end{abstract}

Index terms: ecosystem services, environmental risk, functional lifetime, geoengineering, heterogeneity, public policy.

\section{Sustentabilidade, certificação e regulamentação do "biochar"}

\begin{abstract}
Resumo - O "biochar" tem um tempo de meia-vida no solo relativamente longo e pode alterar substancialmente as propriedades, processos e funções do solo. A perspectiva da aplicação de "biochar" aos solos, em escala global, evidencia a importância de se lhe atribuir um processo de certificação sofisticado e rigoroso. O objetivo deste trabalho foi discutir o conceito da integração das propriedades do "biochar" com os fatores ambientais e socioeconômicos relevantes do local de aplicação selecionado, como parte de um procedimento de certificação sustentável que otimize a complementaridade e a compatibilidade entre esses fatores, em períodos de tempo relevantes. Os efeitos e o comportamento do "biochar" devem, também, ser modelados em escalas temporais similares às de seu tempo de vida funcional nos solos do local selecionado. Finalmente, onde os dados existentes sobre as características do solo forem insuficientes, procedimentos de amostragem e análise do solo devem ser descritos como parte do procedimento de certificação do "biochar".
\end{abstract}

Termos para indexação: serviços ambientais, risco ambiental, tempo de vida funcional, geoengenharia, heterogeneidade, políticas públicas.

\section{Introduction}

Biochar is commonly defined as charred biomass, produced with the intent to apply to soils as a means of sequestering carbon while concurrently improving soil properties (Lehmann \& Joseph, 2009; Verheijen et al., 2010).

The structural and chemical composition of biochar is highly heterogeneous within a sample, and variable between different biochar samples. Some properties are pervasive throughout all biochars, including their dark color, $\mathrm{pH}$, which is typically neutral to basic (although under specific conditions it can also be acidic), high-C content and degree of aromaticity (which partially explains the high levels of biochar's inherent recalcitrance). Nevertheless, the exact structural and chemical composition of each biochar is dependent on a combination of the feedstock type and the pyrolysis conditions used. These same parameters are also key in determining particle size and pore size distribution in biochar, ultimately influencing its functional behavior, mobility and fate in the environment (Verheijen et al., 2010). Charcoal produced by wildfires, or 'pyrogenic black carbon' (BC), is a potential analogue for biochar. Preston \& Schmidt (2006) showed an overview of studies on non-forested sites world-wide in which BC was found to make up 1 to $80 \%$ of total soil organic carbon. There is no evidence that this $\mathrm{BC}$ has caused any deleterious effects, however, it is important to recognize that the composition, properties and application rate of biochar (including scale) can be substantially different to pyrogenic $\mathrm{BC}$ in soils. This reduces the validity of using $\mathrm{BC}$ as a biochar analogue for a certification procedure.

Soils have been shown to exhibit substantial variation in properties at scales relevant to biochar 
application and sustainable biochar systems: regional, catchment, between-fields, and within-field scales (Burrough, 1983). Although large expanses of relatively homogeneous soils do exist, it is commonplace to find contrasting soil types - exhibiting various structural, textural, hydrological, biological and pedological behaviors - within a catchment or between fields, and sometimes even within a field. Furthermore, the border between contrasting soil types can be gradual or sharp within relatively short distances (e.g. within tens of meters). This implies that sustainable biochar application to soil would need to explicitly consider spatial heterogeneity from within-field to regional scales.

Potential effects of biochar on soils, as well as on the wider ecosystem/ecotope and socioeconomic landscape, have been identified as positive or negative. Nevertheless, the full range of associated implications of biochar addition to soils has not yet been comprehensively quantified (Verheijen et al., 2010). For instance, the prospect of widespread incorporation of biochar into soil warrants concern over the potential for soil contamination associated to specific biochar components, which are known for their environmental persistence or potential toxicity to biota, such as polycyclic aromatic hydrocarbons (PAHs) and metals (Pakdel \& Roy, 1991; Fernandes \& Brooks, 2003; Bridle \& Prichard, 2004; Brown et al., 2006; Gaskin et al., 2008). Since these compounds in certain biochars are linked primarily to type of feedstock and pyrolysis temperature, a tight control over such processing parameters may decrease the associated possibility for environmental risk. Similarly, it appears that some biochar properties $(\mathrm{pH}, \mathrm{CEC}$, salt content, particle size distribution, brittleness, plant-available water holding capacity, pore size distribution, albedo, etc.), as well as the application method (topsoil incorporation, depth application, top dressing) and the application strategy (quantity and frequency) all need careful consideration with soil heterogeneity. It is crucial that such considerations are included in a sustainable biochar certification procedure.

Before widespread and large-scale use of biochar in soils can be seriously contemplated and developed into policy, there needs to be a robust body of scientific evidence on its full range of implications for soil properties, processes and functions, as well as for the wider environment. However, experimental results have been variable where available (Verheijen et al.,
2010), and causative mechanisms remain largely obscure (Atkinson et al., 2010). This paper discusses conceptually the integration of biochar properties, soil (and wider ecotope) characteristics, as well as relevant socioeconomic conditions, in a sustainable certification procedure that aims to optimize complementarity and compatibility between these factors over relevant time periods. Soil organic carbon monitoring, verification and accounting issues related to biochar are not discussed - for general information see Saby et al. (2008); for a discussion, see Sanderman \& Baldock (2010); for biochar-specific information, see Lehmann \& Joseph (2009).

\section{Sustainability}

In recent years, various drivers have pushed biochar as a topic in research and policy. Three of the main drivers are disposing of organic wastes, abating climate change and helping to achieve food security (Lehmann \& Joseph, 2009; Navia \& Crowley, 2010; Woolf et al., 2010; Jeffery et al., 2011). Increasing soil degradation by threats to soil, i.e. reduced performance of soil functions, is a major concern globally (European Commission, 2006a, 2006b). Both environmental and food security services of soils need to provide against a background of expected population increases and climatic change during the $21^{\text {st }}$ century (Foley et al., 2005; Schröter et al., 2005).

A range of soil conservation measures is already available (European Commission, 2009). However, such procedures are often not implemented, perhaps predominantly due to economic factors. Biochar stands out from these conservation measures due to a strong economic driver in the potential it provides for waste management and in the return-on-investment opportunity that it may deliver to biochar technology producers. In addition, vast economic opportunities could arise for land owners, organic waste producers and governments, if biochar becomes part of global C credit trading schemes.

For biochar to be considered as a sustainable policy option, it is essential to extend R\&D to cover all soil functions (Blum, 1993; European Commission, 2006a, 2006b) and threats to soil, which include soil erosion, decline in soil organic matter, soil compaction, soil sealing, decline in soil biodiversity, soil salinization, soil contamination, and landslides (European Commission, 2006a, 2006b) comprehensively, and 
at several spatiotemporal scales. In addition, R\&D needs to be representative of the environmental and socioeconomic conditions of any site (physical area) under consideration for policy development. Beyond representation of current conditions, true sustainability should be shown by modelling of expected changes in environmental (i.e. global, regional and local climate change), land use, and socioeconomic conditions of any site under consideration, for the same period as the expected functional lifetime of biochar across the different local soil types. This implies a fundamental extension of existing environmental impact and risk assessment studies (Roberts et al., 2010; Shackley et al., 2012).

\section{Certification and regulation}

The International Biochar Initiative recently has put forward a proposal for guidelines for specification of biochar, with the aim of providing a product definition and specification for quality requirements, while ensuring confidence from the consumers. The initiative is welcome. However, the view expressed in this paper is that a robust certification framework should extend beyond a technical description and labelling of the biomass feedstock and biochar material to also include the environmental and socioeconomic context relevant to the site where biochar would be applied to soils (Figure 1). In this context, a certification label of a biochar material should ideally include the following: biochar with properties A, B, C (including concentrations of contaminants), which makes it appropriate for ecotopes with properties D, E, F to grow crop types $\mathrm{G}$ and $\mathrm{H}$, but not crop type $\mathrm{I}$, at biochar application rates of $\mathrm{J}\left(\mathrm{Mg} \mathrm{ha}^{-1}\right.$ per year) every $\mathrm{K}$ years, to $\mathrm{L}\left(\mathrm{Mg} \mathrm{ha}^{-1}\right.$ per year) every $\mathrm{M}$ years, up to a maximum biochar loading capacity of $\mathrm{N}\left(\mathrm{g} \mathrm{kg}^{-1}\right)$. In addition, socioeconomic impact assessments (Shackley et al., 2012) should be performed as part of the certification procedure for scenarios of possible combinations of the above-mentioned factors.

In many cases, it is expected that current confidence in available soil data will not be sufficient to satisfy the required information of a sustainable biochar certification procedure (from regional to within-field scales). Therefore, in these cases, requirements for soil testing will have to be described as part of the certification procedure. The choice of soil parameters and associated sampling designs for soil testing should be informed by the range of potential biochar properties, for any specific site. For example, if for a catchment the main potential feedstock is organic waste with a moderate to high salt content, it would be a sound precaution to identify and delineate those soils which may be vulnerable to salinization or sodification. However, these tests may be obsolete if all potential feedstocks for the catchment have low salt contents.

Any certification/regulation that may be developed for biochar requires sound scientific evidence and recommendations. It will be imperative to provide the scientific evidence to the policy community in a manner that is comprehensive, robust, objective and independent of any conflict of interest. An intergovernmental panel on biochar could potentially provide a mechanism for achieving this. In addition to qualitative assessments, a quantitative meta-analysis of biochar effects on soil functions would provide a useful tool to objectively assess effects and identify gaps, as well as potential clues to causative mechanisms. All data should be made available in a transparent way, with full disclosure of data, statistics and funding - for detailed recommendations see Verheijen et al. (2010). This can imply translation of research papers into English or the posting of experimental results in an online public database.

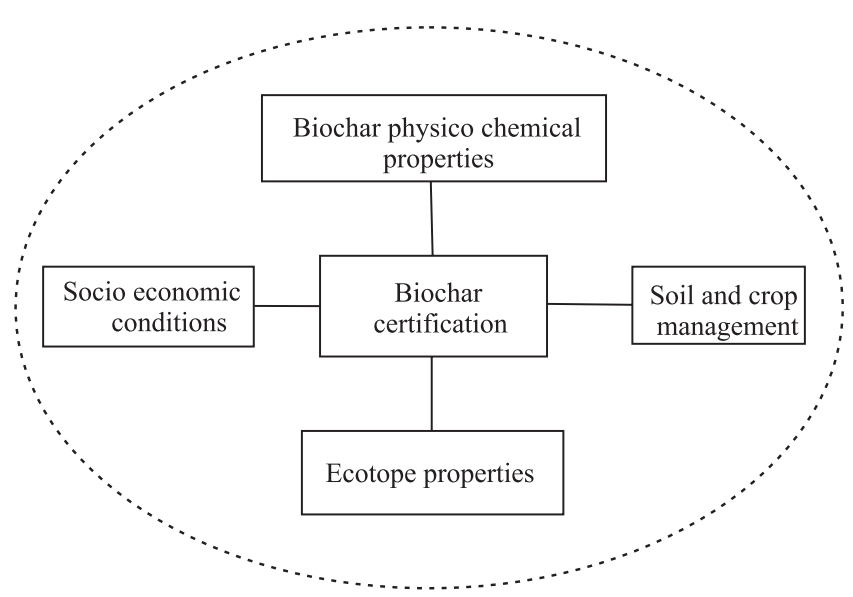

Figure 1. Radial cluster relationship diagram of the desired conceptual integration of the main factors which should be evaluated in a compatibility and complementarity context, into a sustainable biochar certification procedure. Spatiotemporal scale is placed as a dashed oval around the diagram to highlight its importance as a contributing factor to all components of the certification procedure, although potentially at different magnitudes. 
In a sense, the greatest strength of the biochar concept is also its greatest 'weakness'. Its relatively long mean residence time in soils (hundreds of years) make it a potential instrument of C-sequestration (Woolf et al., 2010). At the same time, it may improve one or more soil functions, while avoiding deleterious effects, if compatibility and complementarity are achieved. However, that same long mean residence time sets biochar apart from more conventional soil amendments that are considered as transient in the soil, with functional lifetimes from one to tens of years. The functional lifetime of biochar in soils and its prospect of global-scale application essentially move biochar from a soil management tool to a geoengineering technique (Shepherd, 2009). Moore et al. (2010) divides geoengineering options into two broad categories: solar radiation management, i.e. blocking incoming solar radiation or increasing albedo; and modification of the global carbon cycle, i.e. lowering $\mathrm{CO}_{2}$-atmosphere concentration. Global biochar application qualifies as geoengineering for both categories, since mitigating global climate change by lowering atmospheric albedo is usually stated as one of its main objectives (Woolf et al., 2010), and the soil surface albedo has been shown to decrease after biochar application (Genesio et al., 2012), thereby potentially warming the planet. While biochar may be considered as 'soft geoengineering' (i.e. ecosystem manipulation) in contrast to 'hard geoengineering' (e.g. putting mirrors in space to reflect sunlight away from the Earth), it can be considered 'hard' in terms of reverse-engineering. That is, it can be difficult, laborious and costly to remove biochar from the soils, if at any time that might become desirable. It is, therefore, vital to ensure compatibility and complementarity between biochar, ecotope, socioeconomics and soil and crop management, before biochar is applied to soil (Figure 1).

\section{Final considerations}

Biochar certification should extend beyond characterizing the material itself (the production process and subsequent biochar properties), to include suitable ecotope factors, such as soil physicochemical properties, geomorphology, hydrology, and climate, as well as land management (crop type or rotation, and soil management) and relevant socioeconomic aspects. Sustainable certification should be based on an evaluation of compatibility and complementarity between these factors, include requirements for soil testing, where necessary, and model effects at temporal scales similar to the expected functional lifetime of biochar in soils, at any site under consideration.

\section{Acknowledgements}

To Dr. Simon Jeffery, Dr. Marijn van der Velde and Mr. Iason Diafas, for their scientific support; to the Fundação Portuguesa para a Ciência e a Tecnologia (FCT), for providing Frank Verheijen with a postdoctoral fellowship.

\section{References}

ATKINSON, C.J.; FITZGERALD, J.D.; HIPPS, N.A. Potential mechanisms for achieving agricultural benefits from biochar application to temperate soils: a review. Plant and Soil, v.337, p.1-18, 2010.

BLUM, W.E.H. Soil protection concept of the Council of Europe and integrated soil research. In: EIJSACKERS, H.J.P.; HAMERS, T. (Ed.). Integrated soil and sediment research: a basis for proper protection. Dordrecht: Kluwer Academic, 1993. p.37-47.

BRIDLE, T.R.; PRITCHARD, D. Energy and nutrient recovery from sewage sludge via pyrolysis. Water Science and Technology, v.50, p.169-175, 2004.

BROWN, R.A.; KERCHER, A.K.; NGUYEN, T.H.; NAGLE, D.C.; BALL, W.P. Production and characterization of synthetic wood chars for use as surrogates for natural sorbents. Organic Geochemistry, v.37, p.321-333, 2006.

BURROUGH, P.A. Multiscale sources of spatial variation in soil. I. The application of fractal concepts to nested levels of soil variation. Journal of Soil Science, v.34, p.577-597, 1983.

EUROPEAN COMMISSION. Communication from the Commission to the Council, the European Parliament, the European Economic and Social Committee and the Committee of the Regions: thematic strategy for soil protection. 2006a. Available at: <http://ec.europa.eu/environment/soil/>. Accessed on: 5 June 2012.

EUROPEAN COMMISSION. Proposal for a Directive of the European Parliament and of the Council establishing a framework for the protection of soil and amending Directive 2004/35/EC. 2006b. Available at: <http://ec.europa.eu/ environment/soil.>. Accessed on: 5 June 2012.

FERNANDES, M.B.; BROOKS, P. Characterization of carbonaceous combustion residues: II. Nonpolar organic compounds. Chemosphere, v.53, p.447-458, 2003.

FOLEY, J.A.; DEFRIES, R.; ASNER, G.P.; BARFORD, C.; BONAN, G.; CARPENTER, S.R.; CHAPIN, F.S.; COE, M.T.; DAILY, G.C.; GIBBS, H.K.; HELKOWSKI, J.H.; HOLLOWAY, T.; HOWARD, E.A.; KUCHARIK, C.J.; MONFREDA, C.; PATZ, J.A.; PRENTICE, I.C.; RAMANKUTTY, N.; SNYDER, P.K. Global consequences of land use. Science, v.309, p.570-574, 2005. 
GASKIN, J.W.; STEINER, C.; HARRIS, K.; DAS, K.C.; BIBENS, B. Effect of low-temperature pyrolysis conditions on biochar for agricultural use. Transactions of the ASABE, v.51, p.2061-2069, 2008.

GENESIO, L.; MIGLIETTA, F.; LUGATO, E.; BARONTI, S.; PIERI, M.; VACCARI, F.P. Surface albedo following biochar application in durum wheat. Environmental Research Letters, v.7, 2012. DOI: 10.1088/1748-9326/7/1/014025.

JEFFERY,S.;VERHEIJEN, F.G.A.;VANDERVELDE, M.;BASTOS, A.C. A quantitative review of the effects of biochar application to soils on crop productivity using meta-analysis. Agriculture, Ecosystems and Environment, v.144, p.175-187, 2011.

LEHMANN, J.; JOSEPH, S. Biochar for environmental management: an introduction. In: LEHMANN, J.; JOSEPH, S. (Ed.). Biochar for environmental management: science and technology. London: Earthscan, 2009. p.1-12.

LOUWAGIE, G.; HUBERTUS, S.; BURRELL, A. (Ed.). Final report on the project 'Sustainable Agriculture and Soil Conservation (SoCo)'. Luxembourg: European Commission, 2009. 172p.

MOORE, J.C.; JEVREJEVA, S.; GRINSTED, A. Efficacy of geoengineering to limit 21 st century sea-level rise. Proceedings of the National Academy of Sciences of the United States of America, v.107, p.15699-15703, 2010.

NAVIA, R.; CROWLEY, D.E. Closing the loop on organic waste management: biochar for agricultural land application and climate change mitigation. Waste Management and Research, v.28, p.479-480, 2010.

PAKDEL, H.; ROY, C. Hydrocarbon content of liquid products of tar from pyrolysis and gasification of wood. Energy and Fuels, v.5, p.427-436, 1991.

PRESTON, C.M.; SCHMIDT, M.W.I. Black (pyrogenic) carbon: a synthesis of current knowledge and uncertainties with special consideration of boreal regions. Biogeosciences, v.3, p.397-420, 2006.

ROBERTS, K.G.; GLOY, B.A.; JOSEPH, S.; SCOTT, N.R.; LEHMANN, J. Life cycle assessment of biochar systems: estimating the energetic, economic, and climate change potential. Environmental Science and Technology, v.44, p.827-833, 2010.

SABY, N.P.A.; BELLAMY, P.; MORVAN, X.; ARROUAYS, D.; JONES, R.J.A.; VERHEIJEN, F.G.A.; KIBBLEWHITE, M.; VERDOODT, A.; ÜVEGES, J.B.; FREUDENSCHUß, A.; SIMOTA, C. Will European soil-monitoring networks be able to determine changes in topsoil organic carbon contents? Global Change Biology, v.14, p.2432-2442, 2008.

SANDERMAN, J.; BALDOCK, J.A. Accounting for soil carbon sequestration in national inventories: a soil scientist's perspective. Environmental Research Letters, v.5, 2010. DOI: 10.1088/1748-9326/5/3/034003.

SCHRÖTER, D.; CRAMER, W.; LEEMANS, R.; PRENTICE, I.C.; ARAÚJO, M.B.; ARNELL, N.W.; BONDEAU, A.; BUGMANN, H.; CARTER, T.R.; GRACIA, C.A.; VEGA-LEINERT, A.C. de la; ERHARD, M.; EWERT, F.; GLENDINING, M.; HOUSE, J.I.; KANKAANPÄÄ, S.; KLEIN, R.J.T.; LAVOREL, S.; LINDNER, M.; METZGER, M.J.; MEYER, J.; MITCHELL, T.D.; REGINSTER, I.; ROUNSEVELL, M.; SABATÉ, S.; SITCH, S.; SMITH, B.; SMITH, J.; SMITH, P.; SYKES, M.T.; THONICKE, K.; THUILlER, W.; TUCK, G.; ZAEHLE, S.; ZIERL, B. Ecosystem service supply and vulnerability to global change in Europe. Science, v.310, p.1333-1337, 2005.

SHACKLEY, S.; CARTER, S.; KNOWLES, T.; MIDDELINK, E.; HAEFELE, S.; HASZELDINE, S. Sustainable gasification-biochar systems? A case-study of rice-husk gasification in Cambodia, part II: Field trial results, carbon abatement, economic assessment and conclusions. Energy Policy, v.41, p.618-623, 2012.

SHEPHERD, J. Geoengineering the climate: science, governance and uncertainty. London: The Royal Society, 2009. 82p.

VERHEIJEN, F.; JEFFERY, S.; BASTOS, A.C.; VELDE, M. van der; DIAFAS, I. Biochar application to soils: a critical scientific review of effects on soil properties, processes and functions. Luxembourg: European Commission, 2010. 149p.

WOOLF, D.; AMONETTE, J.E.; STREET-PERROTT, F.A.; LEHMANN, J.; JOSEPH, S. Sustainable biochar to mitigate global climate change. Nature Communications, v.1, 2010. DOI: 10.1038/ncomms 1053 .

Received on December 9, 2011 and accepted on April 12, 2012 